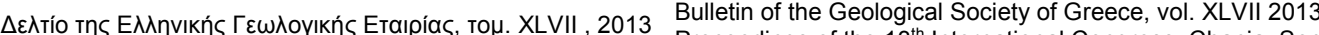
Xroceedings of the $13^{\text {th }}$ International Congress, Chania Sept.

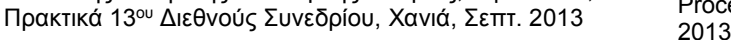

\title{
LANDFORM CLASSIFICATION USING GIS TECHNIQUES. THE CASE OF KIMI MUNICIPALITY AREA, EUBOEA ISLAND, GREECE
}

\author{
Ilia I. ${ }^{1}$, Rozos D. ${ }^{1}$ and Koumantakis I. ${ }^{1}$ \\ ${ }^{1}$ National University of Athens, School of Mining and Metallurgical Engineering, Department of \\ Geological Studies, Laboratory of Engineering Geology and Hydrogeology, Iroon Polytechneiou, \\ 15780,Zografou,Greece, gilia@metal.ntua.gr,rozos@metal.ntua.gr, \\ koumantakisioannis@gmail.com.
}

\begin{abstract}
The main objective of this paper is to classify landforms in Kimi municipality area of Euboea Island, Greece using advanced spatial techniques. Landform categories were determined by conducting morphometric analysis through the use of advanced GIS functions. In particular, the process of classifying the landscape into landform categories was based on Topographic Position Index (TPI).

The main topographic elements such as slope inclination, aspect, slope shape (curvature), topographic wetness index and stream power index were obtained from the DEM file of the study area. Landform classification was obtained using TPI grids and the classes were related with the geological pattern and the land cover by sophisticated spatial analysis function.

The knowledge obtained from the present study could be useful in identifying areas prone to land degradation and instability problems in which landforms are identified as an essential parameter.
\end{abstract}

Key words: Landforms, morphometric analysis, TPI, DEM, Kimi Euboea.

\section{Пврі́ $\eta \psi \eta$}

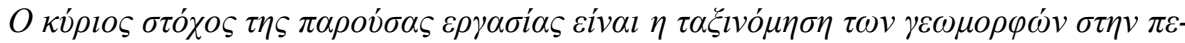

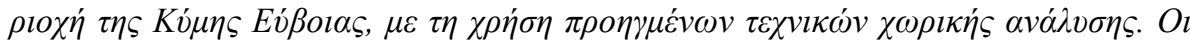

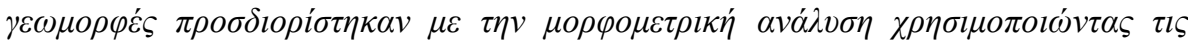

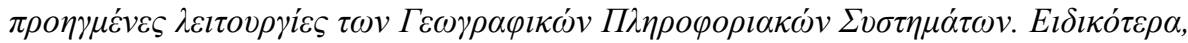

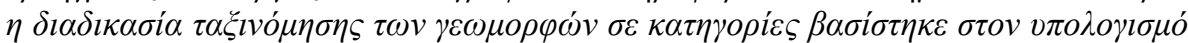

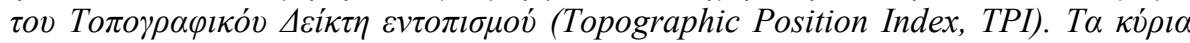

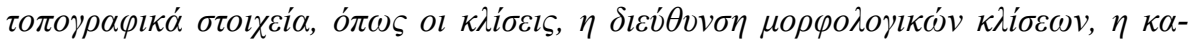

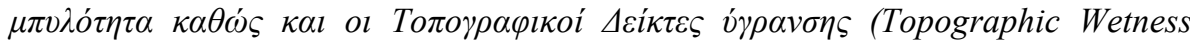

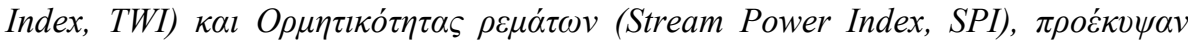

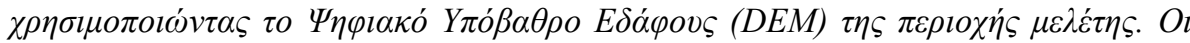

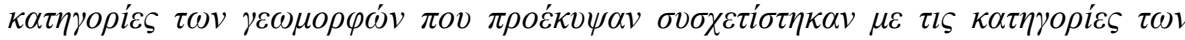

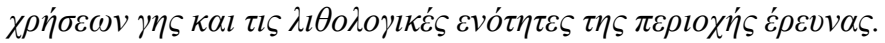

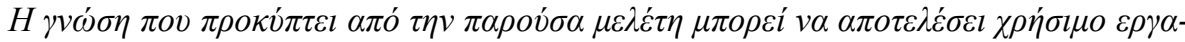

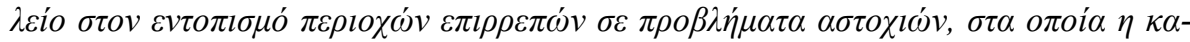

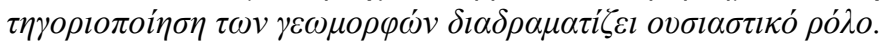

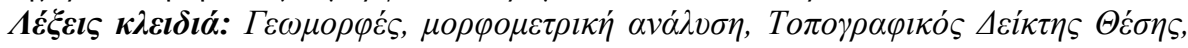

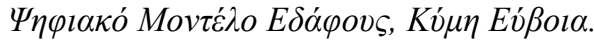

XLVII. No $1-264$ 


\section{Introduction}

The knowledge of the extension and distribution of the landforms, either complex such as ridges, hills and mountains or simple such as highly productive plains and valleys, is very important (Lindenmayer et al, 2006). Currently, there are several researches available which are aimed to the determination and classification of the landforms by using automatic or semiautomatic algorithms (Dehn et al., 2001; Shary et al., 2002; Schmidt et al., 2004; Bolongaro-Crevenna et al, 2005; Jordan et al., 2005; Dragut et al., 2006; Prima et al., 2006; Minár and Evans, 2008, Batuk et al., 2008, Tagil \& Jennesse, 2008, Gercek, 2010).

From a geological and engineering geological point of view, landforms are of specific interest as they were created by geological processes (Karsten et al., 2009). Landforms that develop upon a particular kind of bedrock are related to its structural features such as bedding planes, joints, folds and faults and to its mineralogical composition. In terrain developed upon faulted and eroded sedimentary rocks, there is a strong relationship between rock type, structure, and the ensuing topography. Rock structure determines both major landforms and details of the landscape. Therefore, it is of great significance to determine landform categories and to relate them with geological aspects, land cover and landform classes in a landscape developed or affected by human activities. The existing landforms play a significant role in identifying areas prone to land degradation and instability. Geomorphometry provides a quantitative description of the shapes of landforms and is derived using a combination of mathematics, engineering and computer science (Tagil \& Jennesse, 2008). The possibility of recognizing basic geomorphological features using Digital Elevation Models and Geographic Information Systems Techniques is examined by Gioti (2010) in the area of Antiparos Island, Aegean Sea. Adediran et al. (2004) also demonstrated the ability of the delineated landform elements to be overlaid on any digital map and imagery for further applied research using the application of GIS and multivariate statistical analysis in the area of Crete Island, Greece. In the past, geomorhometric properties were measured calculating the geometry of the relative position with a landform (Blaszczynski, 1997). The field was revolutionized by the computer manipulation of spatial arrays of terrain heights, or digital elevation models (DEMs), which can quantify and depict ground-surface form over large areas (Maune, 2001). Morphometric procedures are routinely implemented by commercial geographic information systems (GIS) and specialized software (Harvey and Eash, 1996; ESRI, 1997; Dikau and Saurer, 1999; Wilson and Gallant, 2000; Guth, 2001).

In this paper, landform categories were determined by conducting geomorphometric analysis through the use of advanced GIS functions, obtaining several topographic gradients from the DEM file of the Kimi area in, Euboea, Greece. These gradients were related with the geological pattern, the land cover and the landform classes by sophisticated spatial analysis function.

\section{Materials and Methods}

\subsection{Geological Settings}

Euboea is the second largest island of Greece and the third largest island of the Eastern Mediterranean sea. It is located eastern of Attica, along the eastern coast of continental Greece (Figure 1). Geologically speaking, in Euboea Island outcrop three tectonic units, the 'Pelagonian Unit', the 'South Euboea Blueschist Belt' and under these units, the 'Almyropotamos Unit' (Aubuin, 1957, Katsikatsos et al. 1986, Katsikatsos, 1991, Shaked et al. 2000). As presented in previous studies (Koumantakis et al, 2008, Ilia et al, 2008, Rozos et al., 2009, Ilia et al., 2010, Tsangaratos et al., 2011), the lithological formations that consist the wide research area are listed as follows (Figure 2):

- Quaternary deposits, which include bed river deposits, debris, fluviatile terraces and dilluvial depositions. 
- Neogene sediments that consist of, calcareous and clayey marls with conglomerate intercalations, as well as base conglomerate.

- Volcanic rocks presented in the south - eastern part of Kimi with dacides - andesites.

- Flysch formation consists of clayey sales, sandstones, conglomerates and limestones.

- Ultrabasic rocks consist of peridotites, dounites and at places serpentinites.

- Carbonate formations usually Mesozoic limestones, and at some places, Palaiozoic ones.

- Granites are outcrop in the Western part of Kimi basin, and they are Carboniferous in age.

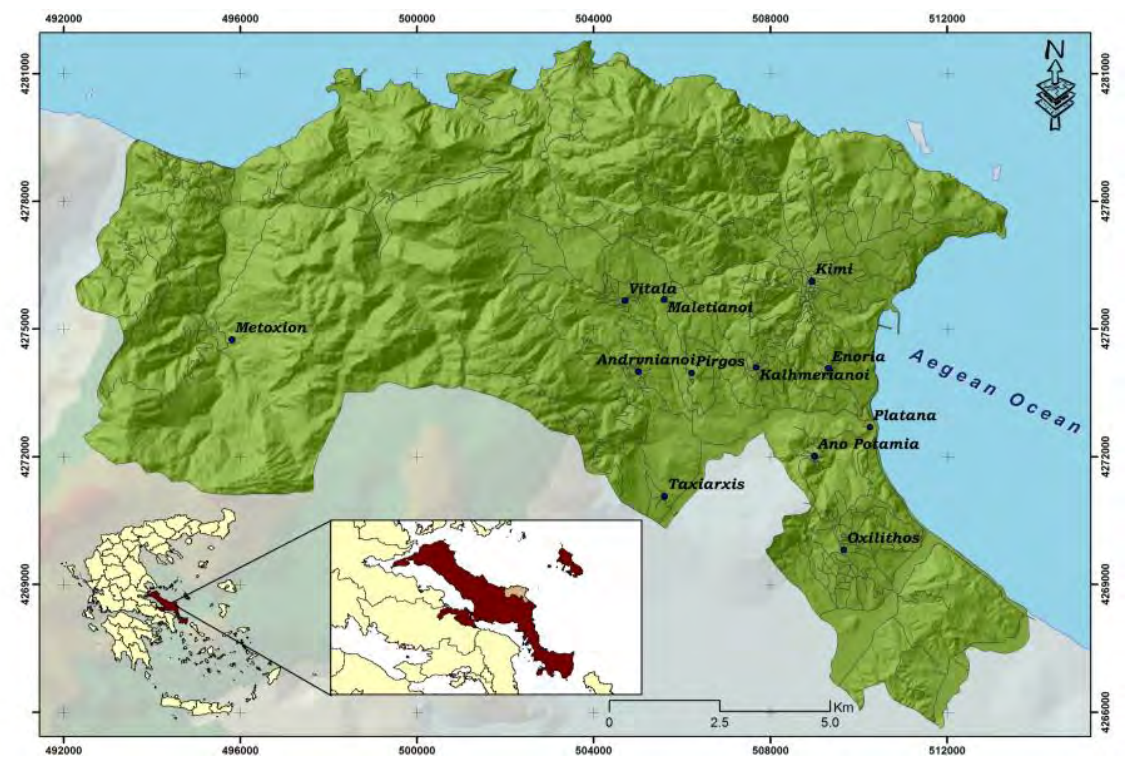

Figure 1 - Study area of Kimi, Euboea Greece.

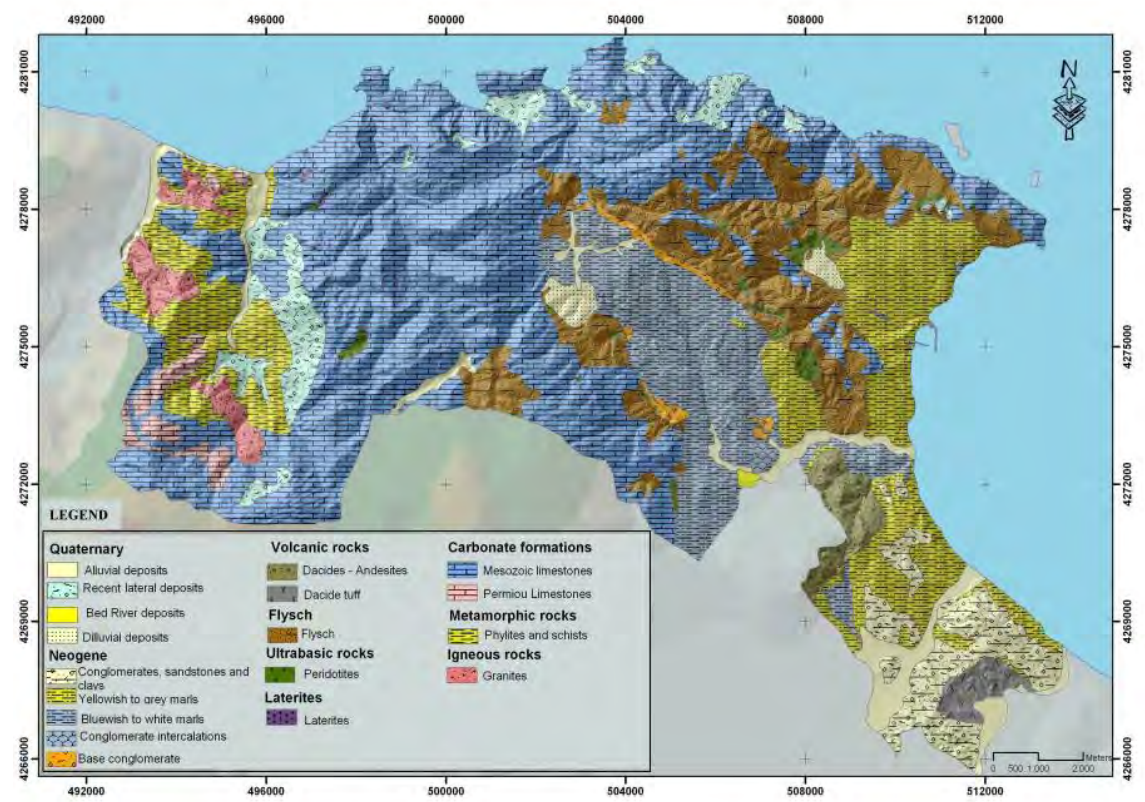

Figure 2 - Geological Map of Kimi Municipality.

XLVII. No $1-266$ 


\subsection{Calculating Topographic Attributes}

The methodology applied in the research area of Kimi, Euboea, Greece and uses the GIS techniques of the software programs ArcView 3.1 and ArcGIS 9.3. The analyzed data included the Digital Elevation Model (DEM) of the Ktimatologio S. A. with 5m resolution, a Geological map of the research area at a scale of 1:25000 (Ilia et al., 2008, Ilia et al., 2010) and the Corine Land cover of 2006 (European Environmental Agency, 2006) (Figure 2, 3). The DEM was used in order to compute the topographic parameters of elevation, slope inclination, aspect, curvature, topographic wetness index and stream power index (Figure 4). Slope inclination and aspect maps show the magnitude and direction of the vector tangent to the topographic surface pointing downhill at a point (Tagil and Jennesse, 2008). ESRI functions were used in order to calculate curvature based on the algorithms of Zevenbergen and Thorne (1987). A 3x3 cell neighbourhood represented the curvature of a $5 \times 5 \mathrm{~m}$ area. Topographic Wetness and Stream Power Indices were used in order to quantify flow intensity and accumulation potential. Topographic Wetness Index (TWI) is also known as Compound Topographic Index (CTI) or Topographic Moisture Index (TMI). TWI at a particular point of the landscape is the ratio between the catchment area contributing to that point and the slope at that point (Wilson and Gallant, 2000):

\section{Equation 1 - Topographic Wetness Index}

$T W I=\ln ($ catchment area/tan $\beta)$,

where $\beta=$ slope in radiants. Higher positive values are wetter and lower negative values are drier.

The Stream Power Index (SPI) was calculated as:

\section{Equation 2 - Stream Power Index}

$S P I=$ catchment areaxtan $\beta$,

where $\beta=$ slope in radiants (Moore et al., 1993).

The SPI is closely related to the Topographic Wetness Index and is used in order to estimate the erosive power of the terrain.

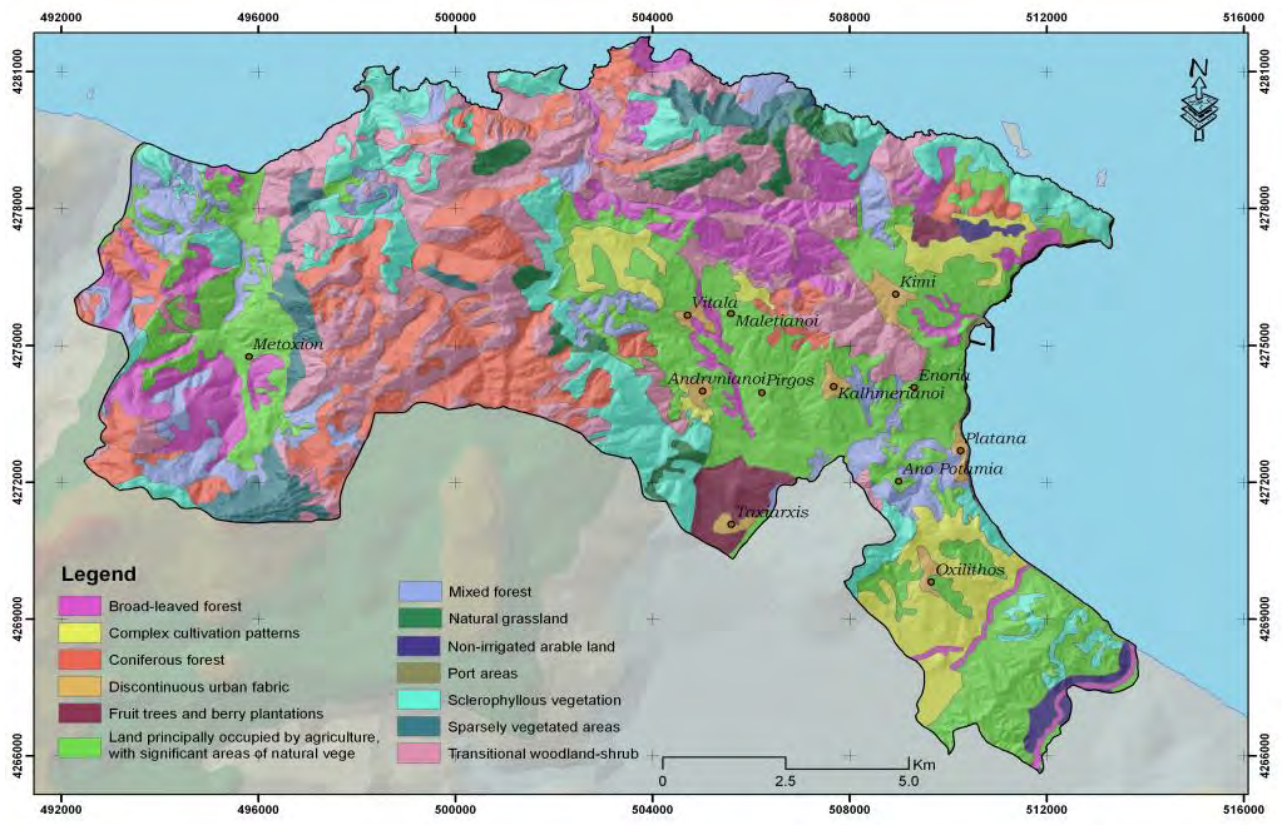

Figure 3 - Land cover classes classified from Corine 2006.

XLVII, No 1 - 267 


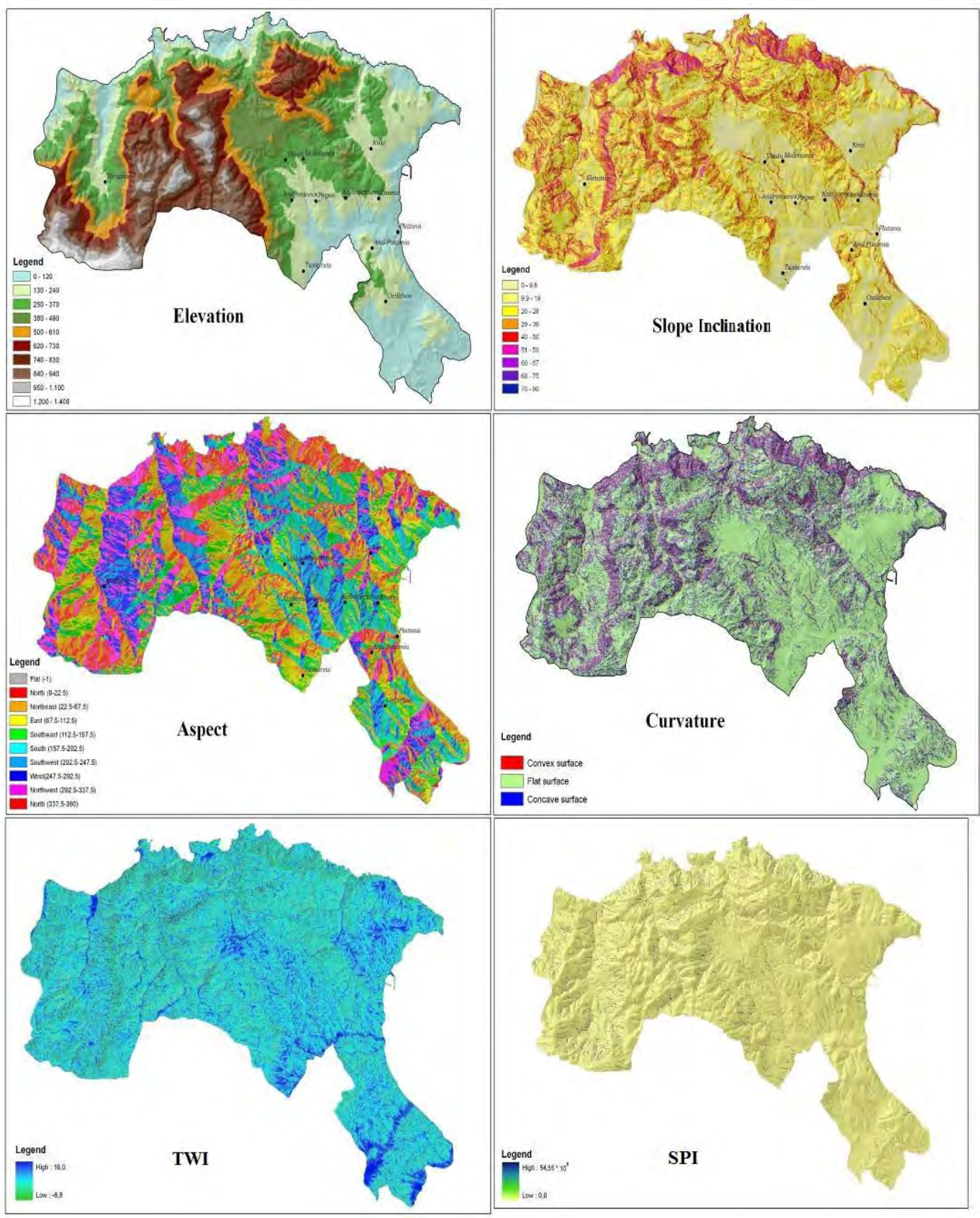

Figure 4 - Topographic attributes: elevation, slope inclination, aspect, curvature, topographic wetness index and stream power index.

\subsection{Calculating TPI}

Topographic Position Index (TPI) is the difference between the elevation at a cell and the average elevation in a cell surrounding that cell. Local mean elevation is subtracted from the elevation value at centre of the local window. An algorithm is provided as an ESRI script by Jenness Enterprises (Jenness, 2006) and it has local window options, which are rectangular, circular and annulus in shape. Positive TPI values represent locations that are higher than the average of the 
local window e.g. ridges. Negative TPI values represent locations that are lower e.g. valleys. TPI values near zero are either flat areas (where the slope is near zero) or areas of constant slope (where the slope of the point is significantly greater than zero), high positive values relate to peaks and ridges (Gercek, 2010).

The neighbourhood size and shape is critical to that analysis and is based on the scale of landscape feature being analyzed. To classify very small features, small neighbourhood is used. To identify large canyons or mountains, we use large neighbourhood (Figure 5).

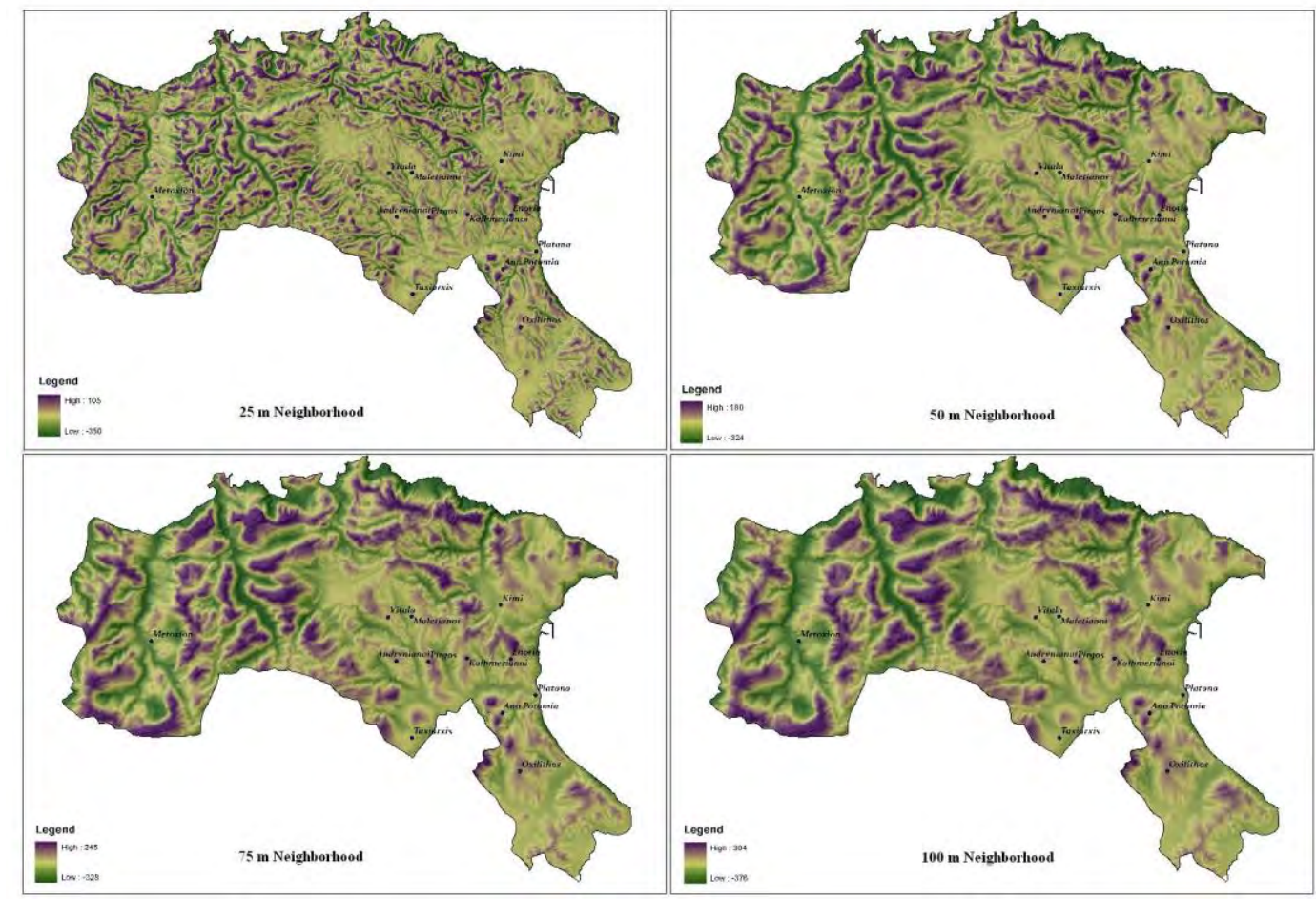

Figure 5 - TPI grids using 4 different neighbourhoods.

\subsection{Landforms Classification}

TPI values calculated from two neighbourhood sizes provide more information about the general shape of the landscape than the TPI values from a single neighbourhood and therefore, more complex landscape features can be identified by combining TPI grids generated at different scales (Tagil and Jenness, 2008). Combining TPI at a small and large scale allows a variety of nested landforms to be distinguished (Figure 6).

As a general rule, since elevation tends to be spatially auto correlated, the range of TPI values increases with scale. One method to address this problem is to standardize the TPI grids to mean $=$ 0 and stdev $=1$. This lets the same basic equations to be used to classify any scale combinations of TPI grids (Weiss, 2001).

In our case, 25 and $100 \mathrm{~m}$ grid in combination with slope were used and classified landforms using criteria described by Weiss (2001). The high and low TPI values were distinguished by setting a threshold of $\pm 1 \mathrm{SD}$, (SD, standard deviation). A full description of each morphological classification is described by Weiss (2001) and Jenness (2006). 


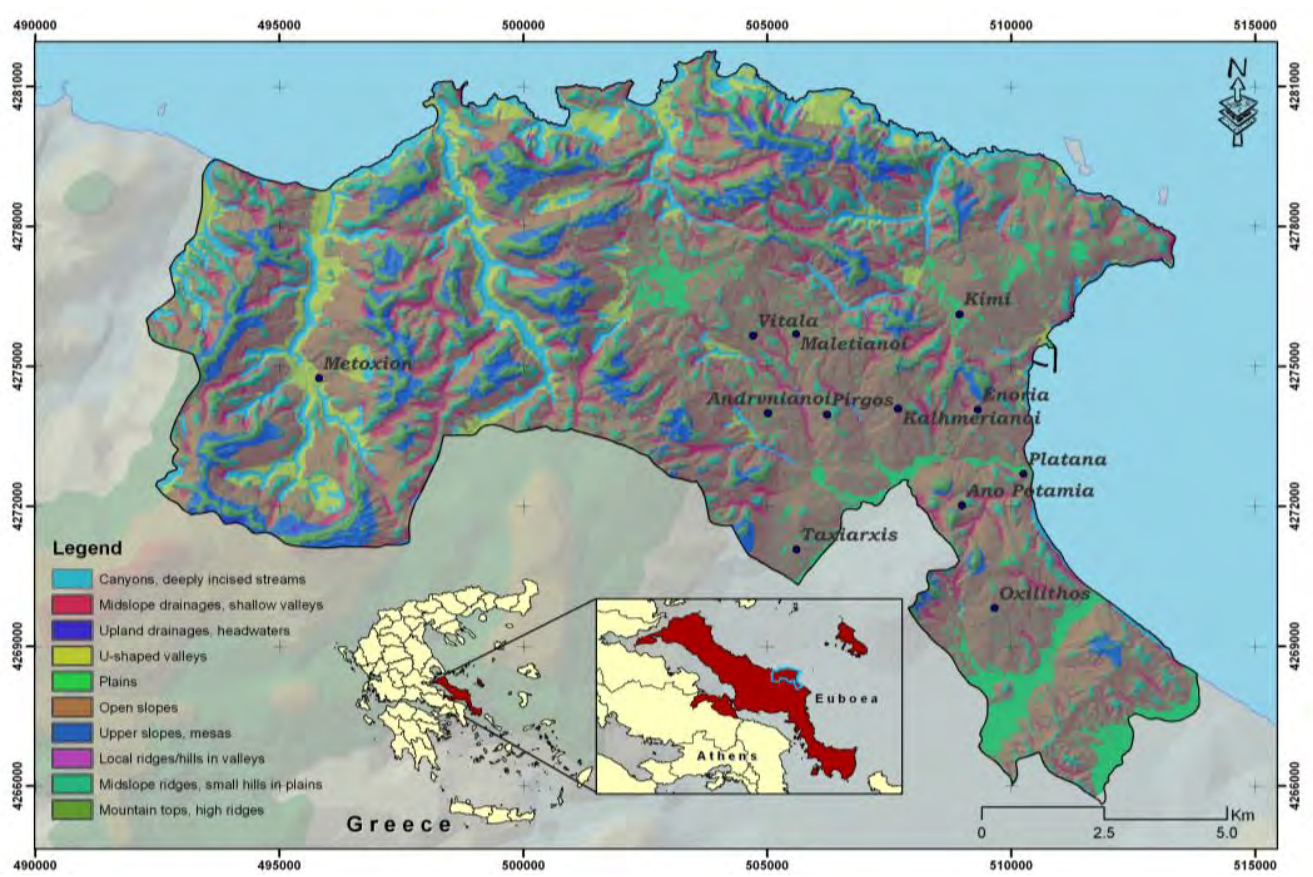

Figure 6 - Landforms using Weiss (2001) classes based on 25 m neighbourhood.

\section{Results and Discussion}

In Figure 7, the percentage of each landform class that covers the research area is provided. Furthermore, the ground truthing was verified by field surveys. The figure shows that the $\sim 54 \%$ of the study area is classified as Open slopes, followed by Upper slopes $(\sim 7.3 \%)$, Mountain tops, high ridges $(\sim 7.2 \%)$, Canyons and deeply incised streams $(\sim 6.9 \%)$ and the other landform classes in smaller percentages. This is attributed to the fact that the area is intersected by several rivers.

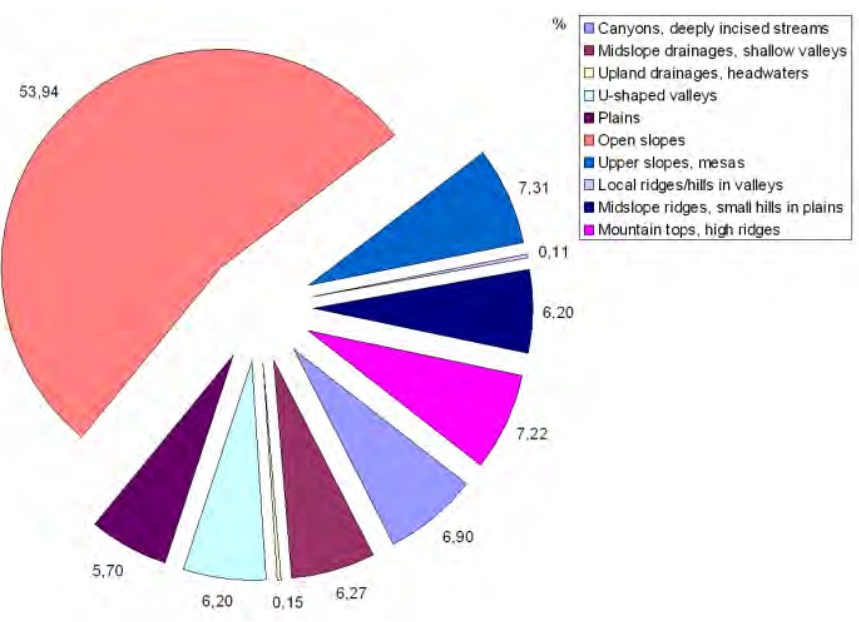

Figure 7 - Landforms using Weiss (2001) classes based on 25 m neighbourhood.

In Tables 1 and 2, the land cover and the lithological units were related with the landform classes, while in Table 3 it is presented the proportion of the lithological units in each landform class.

More specifically, as seen in Table 1, canyons and deeply incised streams (L1) appear to be covered by forest and Transitional woodland-shrub (69.86\%), plains and open slopes (L5 and L6) 
are covered by land principally occupied by agriculture, with significant areas of natural vegetation (37.28\% and 31.72\% respectively) while upper slopes, mesas (L7), local ridges/hills in valleys (L8), midslope ridges, small hills in plains (L9) and mountain tops, high ridges (L10) appear mostly in transitional woodland-shrub (30.82 \%, 36.82 \%, 27.62 \%, 35.28 \% respectively).

Concerning the correlation between the lithological units and the landform classes (Tables 2, 3), it seems that the Quaternary deposits (alluvial deposits, dilluvial deposits, bed river deposits) appear mostly in plains, the marly formations (conglomerates, sandstones and clays, yellowish to gray and bluish to white marls), flysch formations, philites - schists and peridotites appear mostly in open slopes. These areas are prone to slope instability problems and comprise structurally controlled topography, depending on the resistance to weathering and erosion, factors that are interrelated to the mineralogical composition, the cementation, the bedding planes and joints. The recent lateral deposits appear mostly in U-shaped valleys, since they are broken down relatively rapidly by weathering and produce strongly linear or stepped topography.

Table 1 - Landform classes in relation with land cover units (\%).

\begin{tabular}{|l|c|c|c|c|c|c|c|c|c|c|c|c|c|}
\hline LandForm classes & $\mathbf{C 1}$ & $\mathbf{C 2}$ & $\mathbf{C 3}$ & $\mathbf{C 4}$ & $\mathbf{C 5}$ & $\mathbf{C 6}$ & $\mathbf{C 7}$ & $\mathbf{C 8}$ & $\mathbf{C 9}$ & $\mathbf{C 1 0}$ & $\mathbf{C 1 1}$ & $\mathbf{C 1 2}$ & $\mathbf{C 1 3}$ \\
\hline $\begin{array}{l}\text { Canyons, deeply incised } \\
\text { streams (L1) }\end{array}$ & 0.03 & 0.13 & 0.00 & 0.02 & 0.21 & 10.29 & 14.67 & 18.94 & 11.89 & 0.64 & 14.78 & 24.36 & 4.05 \\
\hline $\begin{array}{l}\text { Midslope drainages, shal- } \\
\text { low valleys (L2) }\end{array}$ & 0.30 & 0.14 & 0.01 & 0.44 & 0.41 & 9.79 & 13.76 & 24.01 & 12.16 & 1.13 & 13.57 & 19.40 & 4.89 \\
\hline $\begin{array}{l}\text { Upland drainages, head- } \\
\text { waters (L3) }\end{array}$ & 0.00 & 0.00 & 0.00 & 0.00 & 0.00 & 0.12 & 8.15 & 17.55 & 3.66 & 0.00 & 21.41 & 8.54 & 40.57 \\
\hline U-shaped valleys (L4) & 0.00 & 0.26 & 0.00 & 0.00 & 0.19 & 24.28 & 11.72 & 12.03 & 14.05 & 1.04 & 11.21 & 21.54 & 3.68 \\
\hline Plains (L5) & 3.71 & 0.12 & 7.98 & 2.08 & 25.09 & 37.28 & 10.19 & 2.21 & 3.18 & 0.37 & 3.45 & 4.00 & 0.32 \\
\hline Open slopes (L6) & 1.93 & 0.03 & 0.71 & 2.77 & 7.71 & 31.72 & 9.85 & 11.02 & 7.02 & 1.53 & 10.05 & 13.68 & 1.99 \\
\hline \begin{tabular}{l} 
Upper slopes, mesas (L7) \\
\hline $\begin{array}{l}\text { Local ridges/hills in val- } \\
\text { leys (L8) }\end{array}$
\end{tabular} 0.01 & 0.00 & 0.00 & 0.00 & 0.47 & 5.44 & 6.59 & 17.83 & 4.52 & 7.14 & 17.18 & 30.82 & 10.00 \\
\hline $\begin{array}{l}\text { Midslope ridges, small } \\
\text { hills in plains (L9) }\end{array}$ & 0.40 & 0.00 & 0.07 & 0.32 & 2.95 & 16.02 & 10.53 & 12.74 & 7.69 & 1.82 & 17.95 & 27.62 & 1.90 \\
\hline $\begin{array}{l}\text { Mountain tops, high } \\
\text { ridges (L10) }\end{array}$ & 0.00 & 0.00 & 0.00 & 0.03 & 0.26 & 5.55 & 5.18 & 11.88 & 4.31 & 8.12 & 21.21 & 35.28 & 8.19 \\
\hline
\end{tabular}

C1: Discontinuous urban fabric, C2: Port areas, C3: Non-irrigated arable land, C4: Fruit trees and berry plantations, C5: Complex cultivation patterns, C6: Land principally occupied by agriculture, with significant areas of natural vege, C7: Broad-leaved forest, C8: Coniferous forest, C9: Mixed forest, C10: Natural grassland, C11: Sclerophyllous vegetation, C12: Transitional woodland-shrub, C13: Sparsely vegetated areas.

Table 2 - Landform classes in relation with lithological units (\%).

\begin{tabular}{|c|c|c|c|c|c|c|c|c|c|c|c|c|c|c|c|c|c|c|}
\hline $\begin{array}{l}\text { Landform } \\
\text { classes }\end{array}$ & G1 & G2 & G3 & G4 & G5 & G6 & G7 & G8 & G9 & G10 & G11 & G12 & G13 & G14 & G15 & G16 & G17 & G18 \\
\hline L1 & 5.90 & 4.21 & 0.00 & 0.17 & 0.00 & 4.3 & 1.57 & 0.00 & 0.40 & 0.03 & 0.00 & 8.41 & 0.72 & 0.00 & 61.93 & 2.15 & 6.78 & 3.42 \\
\hline L2 & 0.86 & 0.23 & 0.00 & 0.24 & 1.66 & 5.3 & 6.79 & 0.00 & 0.27 & 3.26 & 0.41 & 14.97 & 1.74 & 0.12 & 56.07 & 1.35 & 4.72 & 2.02 \\
\hline L3 & 0.00 & 0.00 & 0.00 & 0.00 & 0.00 & 0.00 & 0.00 & 0.00 & 0.00 & 0.47 & 0.00 & 4.29 & 0.00 & 0.00 & 88.10 & 0.00 & 2.93 & 4.22 \\
\hline L4 & 7.94 & 8.60 & 0.00 & 0.58 & 0.00 & 1.48 & 1.09 & 0.00 & 0.50 & 0.00 & 0.00 & 4.50 & 0.93 & 0.07 & 60.27 & 1.59 & 8.79 & 3.67 \\
\hline L5 & 26.54 & 0.22 & 0.97 & 3.50 & 6.86 & 13.5 & 25.70 & 0.16 & 0.83 & 0.32 & 2.43 & 7.78 & 0.95 & 0.02 & 8.82 & 0.13 & 0.76 & 0.48 \\
\hline L6 & 0.88 & 0.65 & 0.06 & 0.97 & 6.31 & 14.3 & 15.69 & 0.33 & 1.03 & 1.77 & 1.30 & 13.62 & 1.23 & 0.07 & 34.29 & 0.86 & 5.10 & 1.49 \\
\hline
\end{tabular}




\begin{tabular}{|c|c|c|c|c|c|c|c|c|c|c|c|c|c|c|c|c|c|c|}
\hline L7 & 0.00 & 0.00 & 0.00 & 0.00 & 2.05 & 0.27 & 0.08 & 0.00 & 0.00 & 1.89 & 0.00 & 7.11 & 0.29 & 0.14 & 79.53 & 1.76 & 5.29 & 1.60 \\
\hline L8 & 0.00 & 0.05 & 0.00 & 0.00 & 0.00 & 0.00 & 0.00 & 0.00 & 0.00 & 0.00 & 0.00 & 0.27 & 0.00 & 0.00 & 98.74 & 0.00 & 0.27 & 0.66 \\
\hline L9 & 0.26 & 0.35 & 0.00 & 0.19 & 5.67 & 4.25 & 4.11 & 0.00 & 0.28 & 1.09 & 0.78 & 13.87 & 0.53 & 0.02 & 54.87 & 2.89 & 7.42 & 3.42 \\
\hline L10 & 0.00 & 0.00 & 0.00 & 0.00 & 0.88 & 0.13 & 0.36 & 0.00 & 0.00 & 3.61 & 0.00 & 6.90 & 0.26 & 0.40 & 79.51 & 2.09 & 4.09 & 1.76 \\
\hline
\end{tabular}

G1: Alluvial deposits, G2: Recent lateral deposits, G3: Bed River deposits, G4: Dilluvial deposits, G5: Conglomerates, G6: Yellowish to gray to white marls, sandstones and clays, G7: Bluewish to white marls, G8: Conglomerate intercalations, G9: Base conglomerate, G10: Dacides - Andesites, G11: Dacide tuff, G12: Flysch, G13: Peridotites, G14: Laterites, G15: Limestones, G16: Limestones Permiou, G17: Phyllites and Schists, G18: Granites.

Table 3 - Lithological units in relation with landform classes (\%).

\begin{tabular}{|l|c|c|c|c|c|c|c|c|c|c|}
\hline Lithological units & L1 & $\mathbf{L 2}$ & $\mathbf{L 3}$ & $\mathbf{L 4}$ & $\mathbf{L 5}$ & $\mathbf{L 6}$ & $\mathbf{L 7}$ & $\mathbf{L 8}$ & $\mathbf{L 9}$ & $\mathbf{L 1 0}$ \\
\hline Alluvial deposits (G1) & 13.79 & 1.82 & 0.00 & 16.69 & 51.08 & 16.07 & 0.00 & 0.00 & 0.54 & 0.00 \\
\hline Recent lateral deposits (G2) & 23.73 & 1.20 & 0.00 & 43.60 & 1.02 & 28.68 & 0.00 & 0.00 & 1.76 & 0.00 \\
\hline Bed River deposits (G3) & 0.00 & 0.00 & 0.00 & 0.00 & 63.91 & 36.09 & 0.00 & 0.00 & 0.00 & 0.00 \\
\hline G8: Dilluvial deposits (G4) & 1.46 & 1.86 & 0.00 & 4.51 & 25.04 & 65.62 & 0.00 & 0.00 & 1.51 & 0.00 \\
\hline Conglomerates, sandstones and clays (G5) & 0.00 & 2.34 & 0.00 & 0.00 & 8.73 & 76.28 & 3.36 & 0.00 & 7.87 & 1.42 \\
\hline Yellowish gray to white marls (G6) & 3.12 & 3.49 & 0.00 & 0.96 & 8.08 & 81.27 & 0.21 & 0.00 & 2.77 & 0.10 \\
\hline Bluish to white marls (G7) & 1.00 & 3.93 & 0.00 & 0.62 & 13.51 & 78.28 & 0.05 & 0.00 & 2.36 & 0.24 \\
\hline Conglomerate intercalations (G8) & 0.00 & 0.00 & 0.00 & 0.00 & 4.72 & 95.25 & 0.00 & 0.00 & 0.03 & 0.00 \\
\hline Base conglomerate (G9) & 0.11 & 12.40 & 0.04 & 0.00 & 1.09 & 57.99 & 8.39 & 0.00 & 4.11 & 15.86 \\
\hline Dacides - Andesites (G10) & 3.98 & 2.40 & 0.00 & 4.47 & 6.74 & 79.88 & 0.00 & 0.00 & 2.53 & 0.00 \\
\hline Dacide tuff (G11) & 0.00 & 2.81 & 0.00 & 0.00 & 15.18 & 76.73 & 0.00 & 0.00 & 5.28 & 0.00 \\
\hline Flysch (G12) & 5.06 & 8.18 & 0.06 & 2.43 & 3.85 & 64.05 & 4.54 & 0.00 & 7.50 & 4.34 \\
\hline Peridotites (G13) & 4.93 & 10.79 & 0.00 & 5.70 & 5.37 & 65.93 & 2.13 & 0.00 & 3.28 & 1.89 \\
\hline Laterites (G14) & 0.32 & 8.07 & 0.00 & 4.76 & 1.14 & 43.01 & 10.55 & 0.00 & 1.21 & 30.94 \\
\hline Limestones (G15) & 9.34 & 7.68 & 0.29 & 8.18 & 1.10 & 40.46 & 12.72 & 0.24 & 7.44 & 12.55 \\
\hline Limestones Permiou (G16) & 11.77 & 6.72 & 0.00 & 7.84 & 0.57 & 36.72 & 10.20 & 0.00 & 14.19 & 11.98 \\
\hline Phyllites and Schists (G17) & 8.91 & 5.63 & 0.09 & 10.38 & 0.83 & 52.42 & 7.37 & 0.01 & 8.75 & 5.62 \\
\hline Granites (G18) & 12.53 & 6.71 & 0.34 & 12.07 & 1.46 & 42.65 & 6.20 & 0.04 & 11.25 & 6.75 \\
\hline
\end{tabular}

\section{Conclusions}

GIS techniques were used in order to classify landscape into landform categories, based on Topographic Position Index (TPI). By this method, morphological types were generated for a semi-automated derivation of landform elements according to Weiss (2001). Digital elevation model (DEM) of the research area was a helpful tool in the effort of recognizing landscape morphological characteristics. This study also shows that DEMs offer many more potential habitat descriptors than simply a set of elevation values. Since landforms were created by geological processes and influenced by the land cover, it is of great significance to classify landforms in terms of understanding the potential and constraints within the landscape associated with them. The classification results can be used in applications related to precision agriculture, land degradation studies and spatial modelling applications, where landform is identified as an influential factor in the processes under study. 


\section{Acknowledgments}

This paper is part of the $\mathrm{PhD}$ in progress entitled "Engineering geological features of marls in the wide area of Kimi, Euboea, their impact on construction problems and their treatment". The Authors would like to thank KTIMATOLOGIO S.A. for the supply of the Geospatial Data as well as the ELE of NTUA for the financial supporting of this work.

\section{References}

Adediran A.O., Parcharidis I., Poscolieric M. and Pavlopoulos K. 2004. Computer-assisted discrimination of morphological units on north-central Crete (Greece) by applying multivariate statistics to local relief gradients, Geomorphology, 58, 357-370.

Aubouin J. 1957. Sur la Géologie de la bordure Méridionale de la plaine de Trikkala, Ann. Geol.des P. Hellen., 8, Athènes.

Batuk F., Emem O., Gorum T. and Gokasan E. 2008. Implementation of GIS for Landforms of Southern Marmara. TS 7I - GIS Applications in Turkey, Integrating Generations FIG Working Week 2008, Stockholm, 14-19 June Sweden.

Blaszczynski J.S. 1997. Landform characterization with geographic information systems. Photogrammetric Eng. Remote Sens., 63 (2), 183-191.

Bolongaro-Crevenna A., Torres-Rodriguez V., Sorani V., Frame D. and Ortiz M.A. 2005. Geomorphometric analysis for characterizing landforms in Morelos State, Mexico. Geomorphology, 67, 407-422.

Dehn M., Gartner H., Dikau R. 2001. Principles of semantic modeling of landform structures. Computers \& Geosciences, 27, 1005-1010.

Dikau R. and Saurer H. (eds). 1999. GIS for Earth Surface Systems Analysis and Modelling of the Natural Environment, Stuttgart, Borntraeger, 197 p.

Dragut L., Blaschke T., 2006. Automated classification of landform elements using objectbased image analysis. Geomorphology, 81, 330-344.

Environmental Systems Research Institute (ESRI), Inc., 1997. Watershed Delineator Application User's Manual: Redlands, CA, ESRI, paging unknown.

European Environmental Agency, 2006. CORINE Land Cover, European Environmental Agency, Luxembourg.

Gercek D. 2010. Object - based classification of landforms based on their local geometry and geomorphometric context. PhD Thesis. Department of Geodetic and Geographic Information Technologies. Middle East Technical University.

Gioti E. 2010. Detecting basic geomorphological features using Remote Sensed Data and Geographic Information Systems, Proceedings of the $9^{\text {th }}$ Panhellenic Geographical Conference, Athens, Greece, 633-641.

Guth P.L. 2001. Quantifying terrain fabric in digital elevation models, in Ehlen, Judy, and Harmon, R.S., eds, The environmental legacy of military operations, Geological Society of America. Reviews in Engineering Geology, v. 14, 13-25.

Harvey C.A. and Eash D.A. 1996. Description, instructions, and verification for BASINSOFT, a computer program to quantify drainage-basin characteristics. U.S. Geological Survey, Water-Resources Investigations Report, 95-4287, $25 \mathrm{p}$.

Ilia I., Koumantakis I., Rozos D., Markantonis K. and Tsagaratos P. 2008. Landslide Phenomena in Kimi area, Evia Island, Central Greece, Geophysical Research Abstracts, Vol. 10, EGU2008-A-06831, 2008 SRef-ID: 1607-7962/gra/EGU2008-A-06831 EGU General Assembly 2008.

Ilia I., Tsangaratos P., Koumantakis I. and Rozos D. 2010. Application of a Bayesian approach in GIS based model for evaluating landslide susceptibility. Case study Kimi area, Euboea, Greece. Proc. 12 $2^{\text {nd }}$ International Congress of the Geological Sosciety of Greece.

Jenness J. 2006. Topographic Position Index (TPI) v 1.2. Extension for ArcView 3x. Jenness Enterprices. Available online at web site: http://www.jennessent.com 
Jordan G. and Meijninger B.M.L., Van Hinsbergen D.J.J., Meulenkamp J.E. and Van Dijk P.M. 2005. Extraction of morphotectonic features from DEMs: Development and applications for study areas in Hungary and NW Greece, International Journal of Applied Earth Observation and Geoinformation, 7, 163-182.

Karsten D., Terralogix Consulting and Willem de Frey 2009. Landform classification using GIS. Ekoinfo, PositionIT, GIS Technical, 30-34.

Katsikatsos G., Mettos A., Vidakis M. and Dounas A. 1986. Geological Map of Greece in scale 1:50.000, "Athina-Elefsis" sheet, I.G.M.E. Publ., Athens.

Katsikatsos G. 1991. Geological map of Greece, Aliveri sheet. I.G.M.E. (Institute of Geology and Mineral Exploration, gen. di. V. Andronopoulos).

Koumantakis I., Rozos D., Markantonis K., Ilia I., Tsagaratos P., 2008. Landslide Phenomena of Kimi Municipality. Research Program founded by the Prefecture of Euboea Island.

Lindenmayer D.B. and Fischer J. 2006. Habitat Fragmentation and Landscape Change An Ecological And Conservation Synthesis. Island Press, USA, 2006.

Maune D.F., (eds), 2001. Digital Elevation Model Technologies and Applications, the DEM Users Manual. Bethesda, MD, American Society for Photogrammetry \& Remote Sensing, 540 p.

Minár J., Evans I. S. 2008. Elementary forms for land surface segmentation: The theoretical basis of terrain analysis and geomorphological mapping. Geomorphology 95, 236-259.

Moore I.D., Gessler P.E., Nielsen G. A. and Peterson G. A., 1993. Soil attribute prediction using terrain analysis. Soil Sci. Soc. Am. J., 57 (2): 443-452.

Prima O., Echigo A., Yokoyama R. and Yoshida T. 2006. Supervised landform classification of Northeast Honshu from DEM-derived thematic maps. Geomorphology 78, 373-385.

Rozos D., Koumantakis I., Ilia I., Markantonis K. and Tsangaratos P. 2009. Urban suitability assessment in the area of Vitala Kimi. Research Program founded by the Prefecture of Euboea Island.

Schmidt J. and Hewitt A. 2004. Fuzzy land element classification from DTMs based on geometry and terrain position. Geoderma, 121, 243-256.

Shaked Y., Avigad D., and Garfunkel Z. 2000. Alpine high-pressure metamorphism at the Almyropotamos window (southern Evia, Greece). Geol. Mag., 137, 367-380.

Shary P. A., Sharaya L. S., Mitusov A. V., 2002. Fundamental quantitative methods of land surface analysis, Geoderma, 107, $1-32$.

Tagil S. and Jenness J., 2008. GIS-Based Automated Landform Classification and Topographic, Landcover and Geologic Attributes of Landforms around the Yazoren Polje, Turkey, Journal of Applied Sciences 8 (6): 910-921, ISSN 1812-5654, Asian Network for Scientific Information.

Tsangaratos P., Ilia I., Rozos D. 2011. Case Event System for landslide susceptibility analysis. Proc. Second World Landslide Forum, 3-7 October 2011, Rome (in press), 10 pp.

Weiss A. 2001. Topographic position and landforms analysis. Poster presentation, ESRI User Conference. San Diego, CA.

Wilson J.P., and Gallant, J.C., eds. 2000. Terrain analysis-Principles and Applications. Chichester UK \& NY, Wiley, 479 p.

Zevenbergen L. W. and Thorne C. R., 1987. Quantitative analysis of land surface topography. Earth Surface Process and Landforms, 12, 47-56. 